\title{
Bioremediation of Total Soluble Salt of Tannery Effluent Using Halophilic Microbial Consortium
}

\author{
Umar Mustapha ${ }^{1, ~}$, Ezeta Chibugo Loveth ${ }^{1}$, Mustapha Mohammed Bashir ${ }^{2}$, \\ Mohammed Ibrahim Balarabe ${ }^{3}$, Sani Bashir ${ }^{4}$, Tashi Umar Tijjani ${ }^{2}$, Obafemi Anate Anthony ${ }^{5}$, \\ Abdulkarim Ismail Muhammad ${ }^{1}$ \\ ${ }^{1}$ Department of Science Laboratory Technology, Nigerian Institute of Leather and Science Technology, Zaria, Nigeria \\ ${ }^{2}$ Department of Leather and Leather Products Technology, Nigerian Institute of Leather and Science Technology, Zaria, Nigeria \\ ${ }^{3}$ Department of Industrial Chemical Process Technology, Nigerian Institute of Leather and Science Technology, Zaria, Nigeria \\ ${ }^{4}$ Department of Electrical Engineering, Directorate of Works and Infrastructural Development, Nigerian Institute of Leather and Science \\ Technology, Zaria, Nigeria \\ ${ }^{5}$ Department of General Studies, Nigerian Institute of Leather and Science Technology, Zaria, Nigeria
}

\section{Email address:}

mustapha4mina@yahoo.com (M. Umar), lovethezeta22@gmail.com (L. C. Ezeta), bshmustapha2007@yahoo.com (M. B. Mustapha), balarabeibrahim02@gmail.com (I. B. Mohammed), bsgumel@gmail.com (B. Sani), umartashi@yahoo.co.uk (U. T. Tashi), obatony007@yahoo.com (A. A. Obafemi), ismailalab@yahoo.co.uk (I. M. Abdulkarim)

${ }^{*}$ Corresponding author

\section{To cite this article:}

Umar Mustapha, Ezeta Chibugo Loveth, Mustapha Mohammed Bashir, Mohammed Ibrahim Balarabe, Sani Bashir, Tashi Umar Tijjani, Obafemi Anate Anthony, Abdulkarim Ismail Muhammad. Bioremediation of Total Soluble Salt of Tannery Effluent Using Halophilic Microbial Consortium. International Journal of Ecotoxicology and Ecobiology. Vol. 2, No. 3, 2017, pp. 109-118. doi: $10.11648 /$ j.ijee.20170203.13

Received: May 15, 2017; Accepted: June 16, 2017; Published: July 25, 2017

\begin{abstract}
Tannery effluent is known to contain large amount of dissolved salt (such as $\mathrm{NaCl}$ ) used in the preliminary preservation of hides and skin, which is known to be highly soluble and stable in nature, difficult to eliminate and toxic in nature, thereby being a burden to the environment (ecosystem) and human health. The aim of this study is to isolate halophilic organisms from Nigerian Institute of Leather and Science Technology, Zaria tannery dumpsite using selective media. The isolated microbes were characterized microscopically and biochemically using standard methods. The microbes isolated include; Staphylococcus aureus, Bacillus sp, Pseudomonas aeruginosa, and Saccharomyces cerevisiae. The isolates were used for the bioremediation of total soluble salt in the tannery effluent. Before the tannery effluent treatment, physicochemical parameters such as temperature, $\mathrm{pH}$, colour, Biochemical Oxygen Demand (BOD), Chemical Oxygen Demand (COD), chloride content, conductivity, total dissolved solid (TDS) and salinity were determined using standard procedures. The bioremediation of tannery effluent was carried out using the isolated organisms individually and in combination. The highest remediation was observed in the combination of microbial consortium, followed by Saccharomyces cerevisiae, Staphylococcus aureus, Pseudomonas aeruginosa and Bacillus sp. The temperature of the effluent ranges between $27.4^{\circ} \mathrm{C}$ to $27.6^{\circ} \mathrm{C}$ before the bioremediation, which increased to between $28.4^{\circ} \mathrm{C}$ and $32.3^{\circ} \mathrm{C}$ after remediation. Majority of the physicochemical parameters analyzed recorded drastic decrease especially the salinity (7.10 ppt to $1011 \mathrm{ppm})$, conductivity (1788 $\mu \mathrm{S}$ to $1407 \mathrm{mS})$, colour (faint ash to ash), BOD (942 mg/l to $1156 \mathrm{mg} / \mathrm{l}), \mathrm{COD}(1239 \mathrm{mg} / \mathrm{l}$ to $508 \mathrm{mg} / \mathrm{l})$, chloride content $(181.9 \mathrm{mg} / \mathrm{l}$ to $579.8 \mathrm{mg} / \mathrm{l})$, $\mathrm{pH}(6.3$ to 9.1$)$ and TDS (8.20 ppt to $1322 \mathrm{ppm}$ ) respectively. Most of the physicochemical parameters are above the Federal Environmental Protection Agency (FEPA) and Ethiopian Environmental Protection Authority (EEPA) standard safe limit viz; $\mathrm{pH}$ (6.9), Conductivity $\left(2500 \mu \mathrm{Scm}^{-1}\right), \mathrm{BOD}_{5}(50 \mathrm{mg} / \mathrm{l}$ and $200 \mathrm{mg} / \mathrm{l}), \mathrm{COD}(500 \mathrm{mg} / \mathrm{l})$. However, temperature $\left(<40\right.$ and $\left.40^{\circ} \mathrm{C}\right)$ and chloride content $(1000 \mathrm{mg} / \mathrm{l}$ and $600 \mathrm{mg} / \mathrm{l})$ are within the acceptable limits. Also, there is significant difference $(P=0.000$ at 0.005 level of significance) between the chloride content of the tannery effluent before the bioremediation and the chloride content after ten days bioremediation. Thus, it is recommended to use these organisms in combination to remedy total dissolved salt efficiently than in single. Halophiles can be used in bioremediation of total soluble salt in tannery effluent. It is recommended that natural halophilic microbes should be used in the remediation of total soluble salts in preference to chemicals, which may contain heavy metals that cause toxicity and threat to the environment (ecosystem) and human health.
\end{abstract}


Keywords: Bioremediation, Microbial Consortium, Salinity, Tannery Effluent, Physicochemical Parameters, Halophiles

\section{Introduction}

Bioremediation is a waste management technique that involves the use of organisms to remove or neutralize pollutants from a contaminated site. According to the environmental protection agency (EPA), bioremediation is a treatment that uses naturally occurring organisms to break down hazardous substances into less/nontoxic substances [1].

Effluent is an outflowing of water from a natural body of water or from a manmade structure. Effluent is defined by the United States Environmental Protection Agency as Wastewater treated or untreated that flows out of a treated plant, sewer, or industrial outflow. Generally, it refers to wastes discharged into surface water [1]. Tannery effluent is one of the hazardous pollutants which when the untreated tannery effluents are released into the natural water bodies, they tend to cause environmental degradation and increase health risk to human beings. This is largely due to heavy metals, toxic chemicals, chloride, high dissolved salt, and other pollutants [2]. This wastewater is characterized by high offensive odour, turbidity and ash in colour, this vary according to the chemicals used [3].

Bioremediation may occur on its own (natural attenuation or intrinsic bioremediation) or may only effectively occur through the addition of fertilizers, oxygen, etc., that help encourage the growth of the pollution-eating microbes within the medium (bio-stimulation). For example, the US Army Corps of Engineers demonstrated that windrowing and aeration of petroleum-contaminated soils enhance bioremediation using the technique of land farming [4]. Depleted soil nitrogen status may encourage biodegradation of some nitrogenous organic chemicals, [5] and soil materials with a high capacity to adsorb pollutants may slow down biodegradation owing to limited chemicals to microbes [6]. Recent advancements have also proven successful via the addition of matched microbial strains to the medium to enhance the resident microbe's population ability to break down contaminants. Microorganisms used to perform the function of bioremediation are known as bioremediators [7]. Remediation is to find a remedy for neutralizing a toxin using living things due to their metabolic activity. In other words, remediation is done in order to break down or remove toxins and harmful substances from soil and water using biological origins [8].

Tannery is one of the oldest industries in the world. It is a place where hides are tan to leather or place where tanning is carried out and is typically characterized as pollutantsgenerating industries which produce wide varieties of high strength toxic chemicals. It is recognized as a serious environmental threat due to high chemical levels including salinity, organic load (chemical oxygen load or demand, biological oxygen demand), inorganic matter, dissolved, suspended solids, ammonia, nitrogen, specific pollutants (sulfide, chromium, chloride, sodium and other salt residues) and heavy metals etc. [9], [10], [11].

Large quantity of water is used in tanning process of which $90 \%$ of the water is discharged as effluent. As part of the leather processing, solid and gaseous wastes are also discharged into the environment. During the chrome tanning process, $40 \%$ unused chromium salts are usually discharged in the final effluents, causing a serious threat to the environment [9], [11], [12].

Microbes are effective and environment friendly in the control of pollution due to tannery effluent. The microbes have remarkable power to degrade and utilize complex organic substance and changing it to less toxic and simpler compound [13]. Tannery saline water, which is a primary effluent stream in leather processing industry, is generated by soaking the salt-laden hides and skin in fresh water to remove excess salt. The presence of high salinity $(1-10 \% \mathrm{NaCl} \mathrm{w} / \mathrm{v})$ in this waste stream hinders treatment by chemical means. A biomass sludge adapting to varying saline concentrations (salt-tolerant strains) is required to degrade the dissolved organics present in tannery saline wastewater. Several groups have made significant contribution to biological treatment of saline wastewater [14], [15], [16]. Previous researchers treated wastewater rich in halogenated organics at different salt concentration. Some studied the treatment of hypersaline wastewater by a moderate halophile in a sequencing batch reactor and biofilm reactor [17]. The focus was on salttolerant bacterial strains and their mixed consortium isolated and identified from saline environments. Since the salinity levels of tannery saline wastewater varies every day, a detailed study was undertaken over aboard in saline concentration. Corresponding Chemical Oxygen Demand removal by the identified salt-tolerant strains was followed. The results were compared with those obtained when commercial tannery activated sludge was treated, and variations in degradation efficiency with salt concentration were determined [15].

Halophilic organisms are group of biological organisms that are salt loving which can be used to treat salt content in tannery effluent. Salinity is among the significant abiotic stresses adversely affecting plant development and yield for a wide range of crops. Abiotic stresses like salinity, cold, drought, and high temperature adversely affect the development and productivity of crop plants. Salinity and drought are becoming particularly widespread in many regions and may cause serious salinization in more than 50\% of all arable lands by the year 2050 [18]. However, the adverse effect of salinity in the tannery effluent is a serious issue that can cause a long-term effect on plants and animals which consume water contaminated with hypersaline disposed effluents.

High salinity represents an extreme environment that relatively few organisms can survive such as halophilic organisms and halo-tolerant organisms. These organisms help 
to degrade, remove or reduce salt content in tannery effluent and other wastewater. The presence of high salinity (1-10\% $\mathrm{NaCl} \mathrm{w/v)} \mathrm{in} \mathrm{this} \mathrm{waste} \mathrm{hinders} \mathrm{other} \mathrm{biological} \mathrm{organisms}$ from participating in degrading other organic and inorganic materials in wastewater [19]. Halophiles flourish in saline environments and can be classified as slightly, moderately or extremely halophilic, depending on their requirement for sodium chloride. Halophilic organisms either accumulate organic compatible solutes to balance the osmotic stress of the environment or produce acidic proteins to increase solvation and improve function in high salinity. Although most marine organisms are slight halophiles, moderate and extreme halophiles are generally more specialized microbes, which inhabit hypersaline environments with salinity higher than in the sea. Hypersaline effluents are produced by various industrial activities. Wastewater rich in both organic matter and salt $\left(>35 \mathrm{~g} \mathrm{~L}^{-1}\right)$, is difficult to treat by conventional wastewater treatment. Hypersaline environments are found all over the world, in arid, coastal, and deep-sea [15], [19].

Exposure to chromium, pentachlorophenol and other toxic pollutants increase the risk of dermatitis, ulcer nasal septum perforation and lung cancer. Without any exceptions there is no effluents treatment plant (ETP) in leather tanning industries in developing countries like Nigeria, the owners of tannery industries are not much concerned about human health and environmental safety [20].

Chloride is introduced into tannery effluents as sodium chloride usually on account of the large quantities of common salt used in hide and skin preservation or the pickling process. Being highly soluble and stable, they are unaffected by effluent treatment and nature, thus remaining as a burden on the environment. Considerable quantities of salt are produced by industries, and the levels can rapidly rise to the maximum acceptable level for drinking water, since most of the untreated tannery effluents are directly discharged into receiving water bodies. Increased salt content in groundwater, especially in areas of high industrial density, is now becoming a serious environmental hazard. High salinity $(1-10 \% \mathrm{w} / \mathrm{v})$ of tannery wastewater makes it difficult to be treated by conventional biological treatment. Salttolerant microbes can adapt to these saline conditions and degrade the organics in saline wastewater. In the present research work, saline remediation ability of halophilic consortium comprising of Pseudomonas, Staphylococcus, Saccharomyces, and Bacillus was used to determine the efficiency of the test organisms in the bioremediation of tannery effluent saline concentration and the rate of changes in the saline concentration. It is therefore recommended that tanners should be encouraged to treat their effluents prior to disposal into receiving water bodies [21].

The aim of this research study is to determine the bioremediation capacity of halophilic microbial consortium on the total soluble salt of tannery effluent, with view to isolate and biochemically characterize halophilic microbes from hypersaline environment, and to analyze the physicochemical parameters of the tannery effluent as well as to analyze the effectiveness of halophilic microbes isolated from hypersaline soil in the biodegradation of salt $(\mathrm{NaCl})$ in untreated tannery effluent. The study also aimed to compare the rate of decrease in saline content before and after the microbial bioremediation.

\section{Materials and Methods}

\subsection{Sample Collection}

A mass of $30 \mathrm{~g}$ of soil sample was collected using a sterile hand trowel at the depth of $25 \mathrm{~cm}$ from tannery dumpsite, Nigerian Institute of Leather and Science Technology, Zaria between August, 2016 and February, 2017 [22]. The soil samples were transported immediately in sterile polythene bags to Microbiology laboratory for processing. On arrival to the laboratory, the soil samples were processed in accordance with the methods of Rabah and Ibrahim [23], with little modifications. The soil samples were cultured on Mannitol Salt agar, Cetrimide agar, Nutrient agar and Sabouraud's Dextrose agar for the selective isolation of Staphylococcus aureus, Pseudomonas aeruginosa, Bacillus and Saccharomyces cerevisiae respectively. A total of $1000 \mathrm{ml}$ of untreated tannery effluent was collected in dark sample bottle from the tannery at Nigeria Institute of Leather and Science Technology, Samaru-Zaria, Kaduna state, Nigeria using a sampler which allows sampling from discrete depth, and transported without agitation or aeration immediately to the Microbiology Laboratory, Ahmadu Bello University, Zaria for analysis [24]. The effluent samples were collected from all the stages of tanning viz; soaking, liming deliming, pickling, chrome tanning and re-tanning combined together ready to be released to the disposal point. On arrival to the laboratory, $500 \mathrm{ml}$ of the sample was dispensed into a separate beaker for physicochemical analysis.

\subsection{Determination of Physicochemical Parameters}

The following physiochemical parameters were immediately analyzed on the tannery effluent and stored at $4^{\circ} \mathrm{C}$ to arrest any biological activity while preparing for the isolate to be ready for the treatment of the effluent. The physiochemical parameters determined in the tannery effluent are: colour, $\mathrm{pH}$, temperature, chloride, Biochemical Oxygen Demand (BOD), Chemical Oxygen Demand (COD), total soluble salt, Dissolve Oxygen (DO), Conductivity, Total Dissolved solid, Turbidity and colour using standard procedures [25]. The effluent sample was filtered using Whatman No. 1 filter paper, and the $\mathrm{pH}$ was adjusted to $<2$ using concentrated Nitric acid $\left(\mathrm{HNO}_{3}\right)$, then, the samples were analyzed for total saline using electric conductivity meter.

The $\mathrm{pH}$ of the effluent was adjusted to neutral 7.0 (Figure 1) using $\mathrm{NaOH}$ and then distributed in $250 \mathrm{ml}$ conical flasks (100 $\mathrm{ml}$ in each). A solution of $1 \%$ sucrose was added and $1 \% \mathrm{McF}$ arland standard of the overnight grown culture was initiated in each conical flask. The isolated microbes were used in single and in combination as adopted by Benazir et al. [26]. The flask was kept at room temperature for 
Saccharomyces cerevisiae at room temperature for 10 days. Bacterial isolates were inoculated into the flask and incubated at $37^{\circ} \mathrm{C}$ for 10 days with gentle mixing each day as described by Benazir et al., [26]. Salinity was estimated at an interval of 24 hours to calculate the saline depletion from the effluent by the different test organisms.

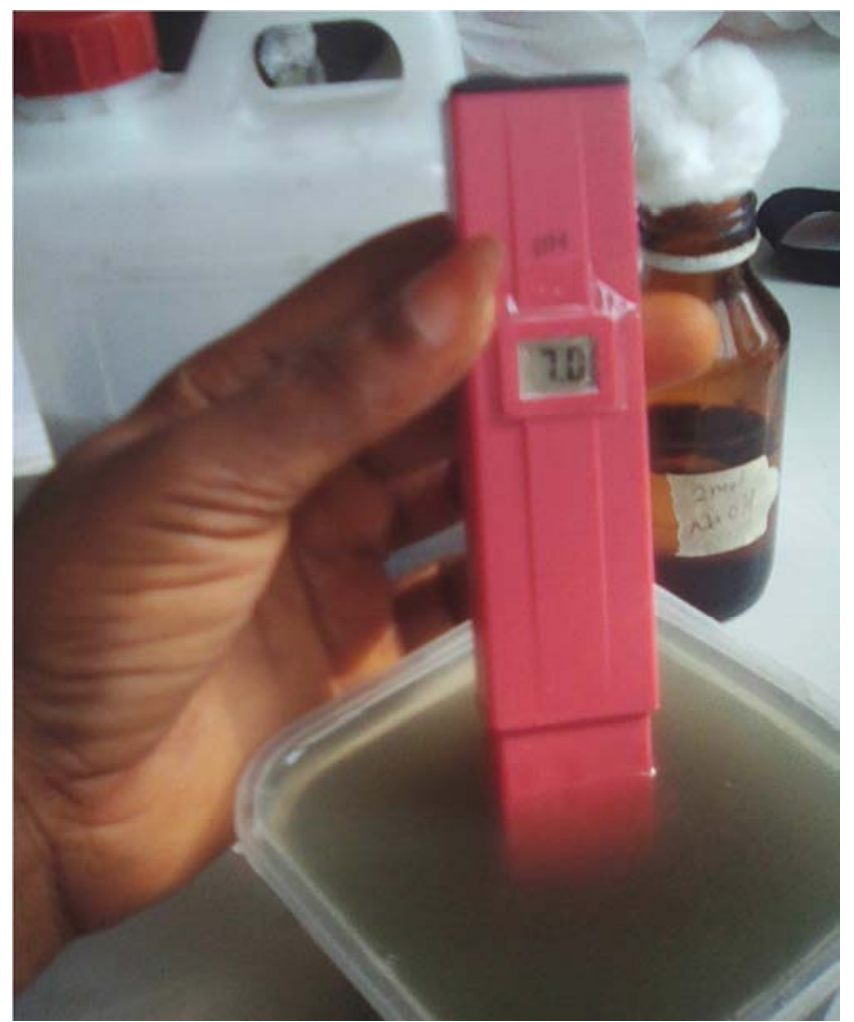

Figure 1. Adjustment of $p H$ of the tannery effluent to neutral prior to bioremediation.

\subsection{Microbial Culture and Maintenance}

The isolated microbial cultures used for the study includes; Staphylococcus aureus, Bacillus sp, Pseudomonas aeruginosa and Saccharomyces cerevisiae, which were identified based on their physiological, morphological and biochemical characteristics [26], [27]. The pure isolates of the halophilic microbes were maintained in their respective selective media, viz; Mannitol salt agar, Nutrient agar, Cetrimide agar and Sabouraud's Dextrose agar for Staphylococcus aureus, Bacillus sp, Pseudomonas aeruginosa and Saccharomyces cerevisiae respectively [26].

\subsection{Characterization of the Bacterial Isolates}

The test organisms were Gram stained to determine their Gram potentials and morphologies. Spore stain was carried out to determine Bacillus species. Biochemical characterizations such as Catalase, Citrate utilization test, Indole test, Coagulase test, Motility test, Methyl Red and Voges Proskauer tests were carried out in accordance with the work of Cheesbrough [27] and Umar et al. [28].

\subsection{Identification of Saccharomyces Cerevisiae}

The isolated yeast was identified by observing its colonial morphology of milky moist irregular colonies (Figure 2) with characteristic baker's bread smell, and microscopic characteristics using a wet mount preparation with lactophenol in cotton blue, which revealed Saccharomyces cerevisiae budding cells [27]. The isolates were further characterized by oxidative-fermentative (OF) test. The medium was prepared according to manufacturer's instruction. A volume of $18 \mathrm{ml}$ of oxidative-fermentative medium was poured into four different beakers each, $2 \mathrm{ml}$ of each was poured into the oxidative-fermentative medium then, $10 \mathrm{ml}$ of each was poured into well label test-tube then, a stab of the isolate was inoculated into the medium respectively, and incubated for 24 hours at $37^{\circ} \mathrm{C}$, after which the medium was observed for colour change [27]. The yeast isolates were inoculated on YPG agar supplemented with 100 $\mathrm{ml}$ ethanol for the determination of flocculation, hydrogen sulphide production, temperature and ethanol tolerances [29], [30].

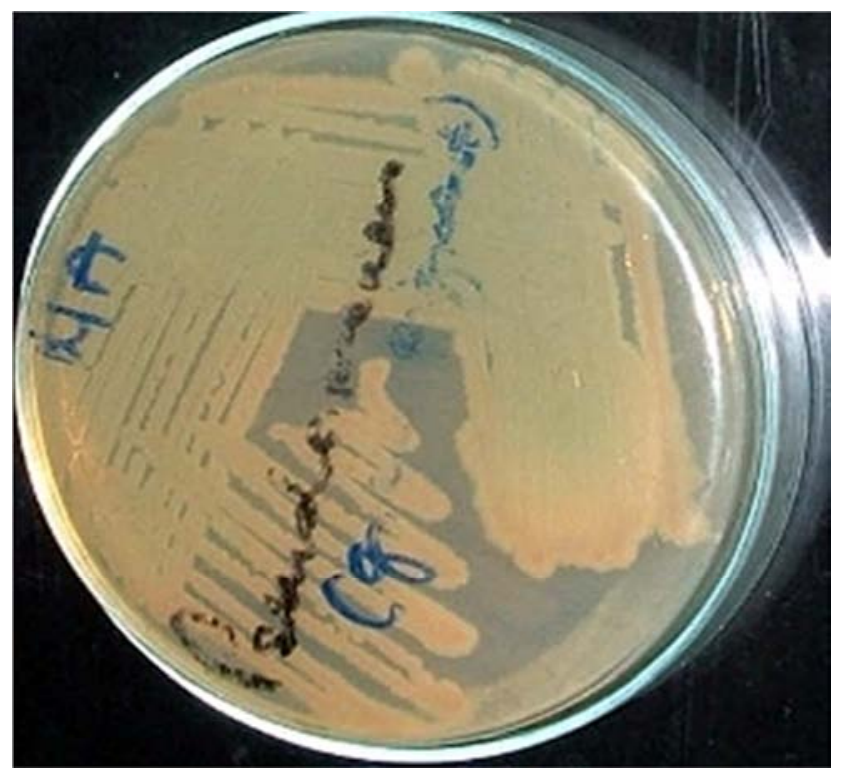

Figure 2. Cultural morphology of Saccharomyces cerevisiae isolated from tannery laden soil.

\subsection{Determination of Physicochemical Analysis of Tannery Effluent}

The physicochemical quality of the collected tannery effluent was determined using the methods described by APHA [31], [32], [33]. The parameters tested are $\mathrm{pH}$, temperature, conductivity, total dissolved solid, salinity, colour, Biochemical Oxygen Demand (BOD), Chemical Oxygen Demand (COD) and chloride content. These parameters were selected because they are considered to be deleterious on the receiving environment and they were included in the discharge limit.

\subsubsection{Determination of $\mathrm{pH}$}

This was determined using $\mathrm{pH}$ meter. A volume of $100 \mathrm{ml}$ 
of tannery effluent sample was collected in $200 \mathrm{ml}$ beaker, then, a buffer solution was used to zero the $\mathrm{pH}$ meter (standardization), then $100 \mathrm{ml}$ of the sample was collected and the electrode of the $\mathrm{pH}$ meter was inserted into the sample (tannery effluent) and the $\mathrm{pH}$ readings was taken [21].

\subsubsection{Determination of Temperature}

This was determined by rinsing the electrodes of multifunctional conductivity meter with distilled water, switched on and allowed to standardize itself (automatic standardization). The conductivity meter was dipped into the sample (tannery effluent), after 5 seconds the readings was recorded as adopted by Douglas [34].

\subsubsection{Determination of Conductivity}

This was determined by rinsing the electrodes of multifunctional conductivity meter with distilled water, switched on and allowed to standardize itself (automatic standardization). Then, the conductivity meter was dipped into the sample for 5 seconds. The reading was then recorded (Figure 3 ) as adopted by Douglas [34].

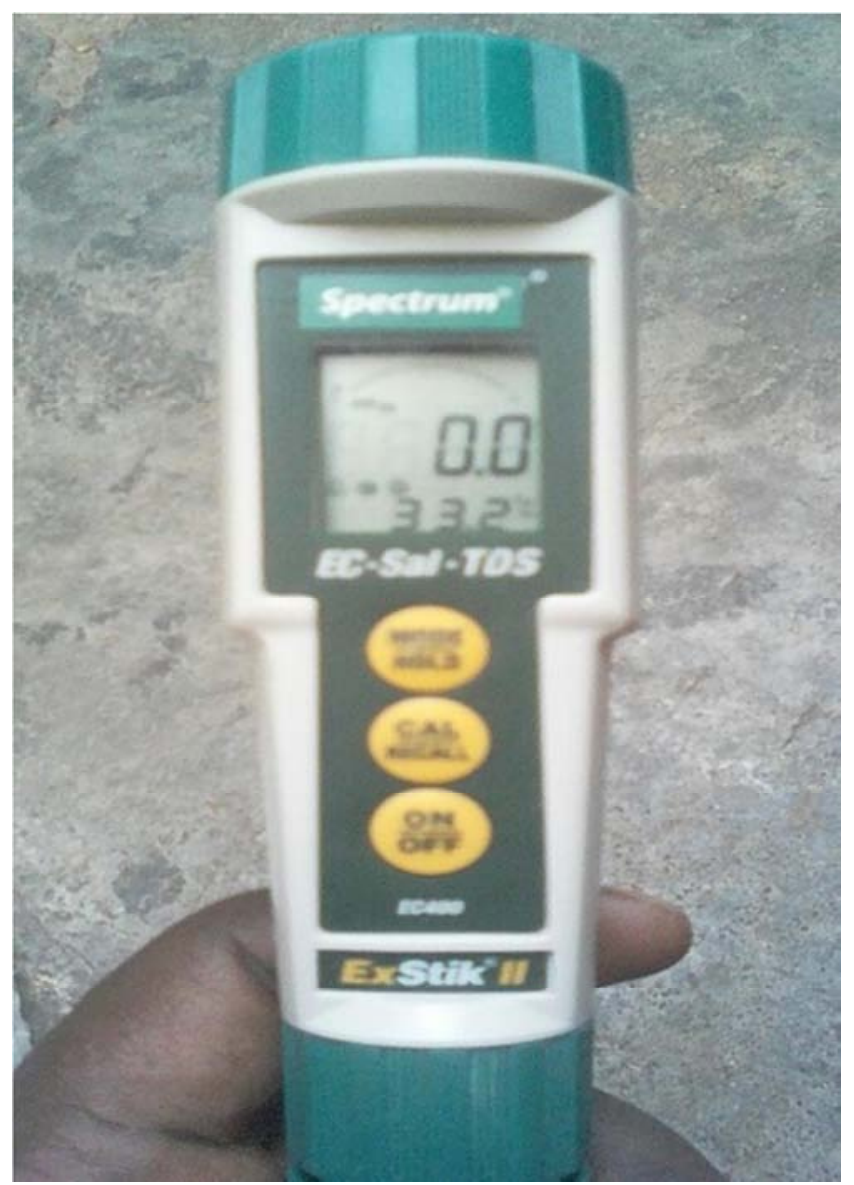

Figure 3. Spectrum ${ }^{\circledR}$ Waterproof Electric Conductivity Meter Used for Physicochemical Analysis.

\subsubsection{Determination of Total Dissolved Solid}

This was determined by rinsing the electrodes of multifunctional conductivity meter with distilled water, switched on and allowed the conductivity meter to standardize itself (automatic standardization). Then, the conductivity meter was dipped into the sample for 5 seconds, and the reading was recorded as adopted by Douglas [34].

\subsubsection{Determination of Salinity}

This was determined by rinsing the electrodes of multifunctional conductivity meter with distilled water, switched on and allowed to standardize itself (automatic standardization). The meter was dipped into the sample for 5 seconds. The reading was recorded as adopted by Douglas [34].

\subsubsection{Determination of Chloride}

A volume of $10 \mathrm{ml}$ of the tannery effluent sample was measured and transferred into conical flask containing $2 \mathrm{ml}$ of hydrogen peroxide $\left(\mathrm{H}_{2} \mathrm{O}_{2}\right)$. Then, $2 \mathrm{ml}$ of potassium chromate indicator $\left(\mathrm{K}_{2} \mathrm{Cr}_{2} \mathrm{O}_{4}\right)$ which was titrated with silver nitrate $(0.0141 \mathrm{~N})$ was used. The end point was observed for colour change (i.e. formation of reddish-yellow). Same was done on blank. The concentration of chloride was determined using the formula in equation (1) as described by APHA [31].

$$
\text { Chloride }(\mathrm{mg} / \mathrm{L})=\frac{(\mathrm{A}-\mathrm{B}) \times \mathrm{N} \times 35.45 \times 1000}{\text { volume of sample }}
$$

Where: $\mathrm{A}=\mathrm{ml}$ titration of sample, $\mathrm{B}=\mathrm{ml}$ titration for blank, $\mathrm{N}=$ Normality of $\mathrm{AgNO}_{3}$, molar weight of $\mathrm{AgNO}_{3}=35.45$

\subsubsection{Determination of Biochemical Oxygen Demand (BOD)}

A volume of $1000 \mathrm{ml}$ of sterile distilled water was aerated for 3.5 hours, and nutrients were added such as (calcium chloride solution, Magnesium sulphate solution, ferric chloride solution and phosphate buffer solution) to the aerated distilled water and aerate again for 30 minutes. Amber colored bottles for the determination of Biochemical Oxygen Demand (BOD) were labeled appropriately. A volume of $30 \mathrm{ml}$ of the sample was measured using measuring cylinder and transferred into each of the BOD bottle. Then, the remaining space was filled with dilution water and the bottles were carefully covered immediately to avoid air bubbles. $\mathrm{BOD}_{5}$ bottles were incubated in dark place at $20^{\circ} \mathrm{C}$ for 5 days. Immediately, the remaining diluted samples and blank were analyzed for DO; a volume of $1.2 \mathrm{ml}$ of $\mathrm{MnSO}_{4}$ was added, then, $2 \mathrm{ml}$ of alkali-iodideAzide all deeply inside the sample and blank. The floc was allowed to settle, then $2 \mathrm{ml}$ concentrated $\mathrm{H}_{2} \mathrm{SO}_{4}$ was added to dissolve the floc immediately. Exactly $200 \mathrm{ml}$ of the sample was measured and transferred to a beaker, and $3 \mathrm{ml}$ of starch solution was added and titrated with $0.025 \mathrm{~N}$ of sodium thiosulphate. The end point colour changes from purple to colourless. The result was recorded after 5 days. Same was done for blank and sample for $\mathrm{BOD}_{5}$, and the value was calculated using equation (2) as described by APHA [31].

$$
\operatorname{BOD}\left(\frac{\mathrm{mg}}{\mathrm{l}}\right)=\frac{(\text { Do }-\mathrm{Dn}-\mathrm{Bl}) \times \text { volume of BOD bottle }}{\text { volume of sample used }}
$$


Where: Do=initial dissolve oxygen (Do) of diluted sample, $\mathrm{Dn}=$ final dissolve oxygen (Do) of diluted sample after 5 days, $\mathrm{Bl}=\mathrm{Blank}$ (initial-final)

\subsubsection{Determination of Chemical Oxygen Demand (COD)}

Three test-tubes were labeled appropriately. Exactly $2.5 \mathrm{ml}$ of the sample was measured with syringe and needle, and was transferred into two test-tubes each. Then, $2.5 \mathrm{ml}$ of distilled water was dispensed into the remaining test-tubes. A volume of $1.5 \mathrm{ml}$ of $0.25 \mathrm{~N}$ potassium dichromate was added to each of the 3 test-tubes. Carefully and gently, $3.5 \mathrm{ml}$ of concentrated sulphuric acid was added to each of the 3 testtubes and tightly closed with absorbent cotton wool and incubated in the hot oven at $150^{\circ} \mathrm{C}$ for 2 hours. After 2 hours, the tests tubes were brought out and allowed to cool to room temperature. Meanwhile, a clean burette was filled with ferrous ammonium sulphate and was carefully dispensed into each of the test-tubes. The solution was transferred into a conical flask. Then 2 drops of ferroin indicator was added to it and titrated against ferrous ammonium sulphate until the colour changes to reddish brown. The reading of the burette was recorded. The same was repeated for the second sample and blank test-tubes, and the value was calculated using equation (3) as described by APHA [31] and Clesceri et al. [25].

$$
\mathrm{COD}(\mathrm{mg} / \mathrm{l})=\frac{(\mathrm{A}-\mathrm{B}) \times \mathrm{N} \times 8 \times 1000}{\text { volume of sample taken }}
$$

Where: $A=$ volume of Ferrous Ammonium sulphate for blank, $\mathrm{B}=$ volume of Ferrous Ammonium sulphate for sample, $\mathrm{N}=$ Normality of Ferrous Ammonium sulphate

The determination of colour and turbidity was done by physical visual comparison method [35].

\section{Results and Discussion}

Table 1, below showed the microscopic and biochemical characterization of the microbes isolate from the soil. The predominant organisms were found to be positive to indole, catalase, Voges-Proskauer (VP), citrate and coagulase. The bacterial isolates grown on nutrient agar were found to be spore-forming, non-motile and methyl red negative. Therefore, they are identified as Bacillus sp. The bacterial isolates that are coagulase negative, motile and methyl red negative and grown on Cetrimide agar were identified as Pseudomonas aeruginosa. The bacterial isolates that are methyl red positive, non-motile and grown on mannitol salt agar were identified as Staphylococcus aureus. While the yeast species grown Sabouraud's dextrose agar that showed budding cells by microscopy and positive to glucose, lactose, sucrose and maltose were identified as Saccharomyces cerevisiae.

Table 1. Microscopic and Biochemical Characterizations of the Microbes Isolated from Tannery Dumpsite Soil.

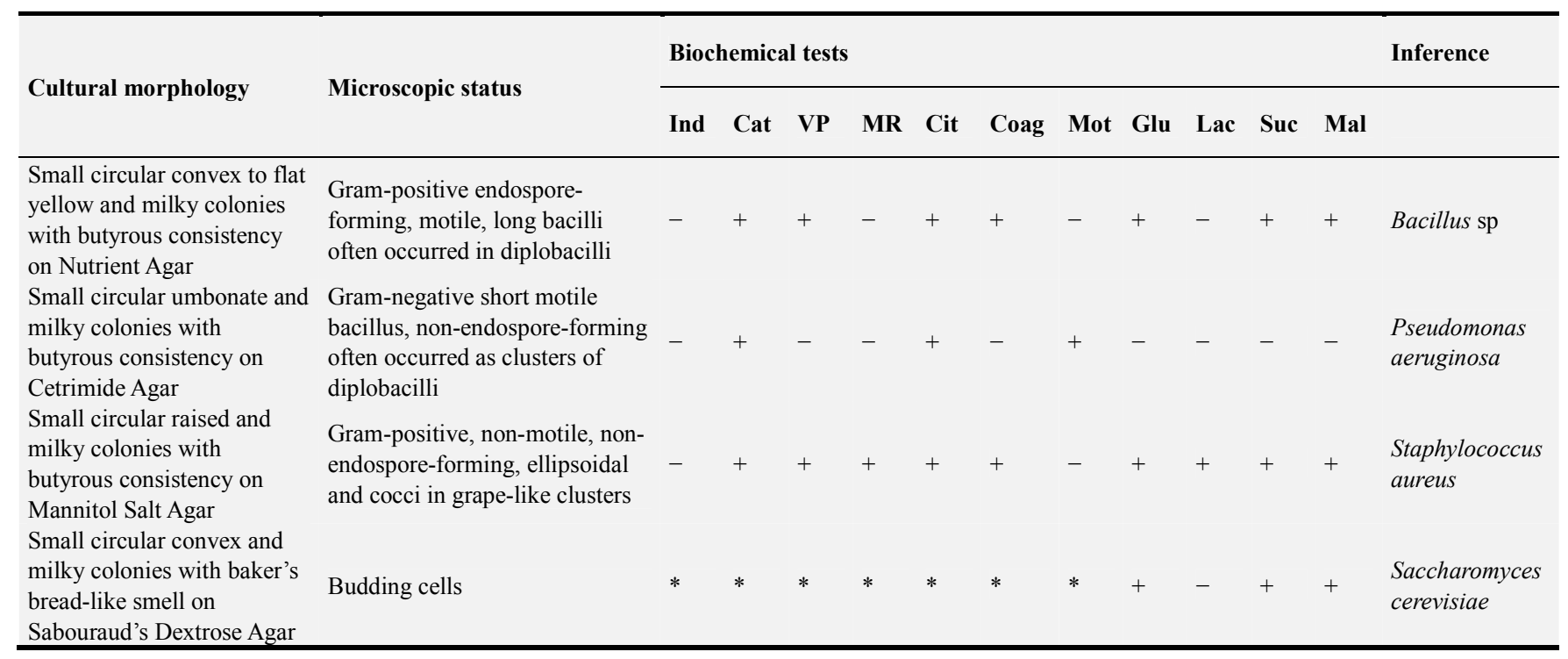

Keys: $\mathrm{CA}=$ Cetrimide agar; $\mathrm{MSA}=$ Mannitol salt agar; NA= Nutrient agar; $\mathrm{SDA}=$ Sabouraud's dextrose agar; $+=$ positive; $-=$ negative; Cat $=\mathrm{Catalase}, \mathrm{VP}=$ Voges-Proskaue, MR=Methyl red, Cit=Citrate, Coag= Coagulase, Mot= Motility, Glu=Glucose, Lac= Lactose, Suc $=$ Sucrose, Mal= Maltose. $*=$ not applicable

Table 2 shows physicochemical analysis of the tannery effluent at the beginning and end of the bioremediation process. The temperature of the effluent ranges between 27.4 to $27.6^{\circ} \mathrm{C}$ with ash coloration before the bioremediation process, Biochemical oxygen demand (BOD), Chemical oxygen demand (COD) and chlorine contents were found to be $942 \mathrm{mg} / \mathrm{l}, 508 \mathrm{mg} / \mathrm{l}$ and $579.8 \mathrm{mg} / \mathrm{l}$ respectively. The conductivity ranges from 1788 to $1903 \mu \mathrm{S}$, with total dissolved solids ranging between 1253 to $13223 \mathrm{ppm}$. After remediation, the $\mathrm{pH}$ ranged between 8.1 to 9.1 at the temperature range of $28.4^{\circ} \mathrm{C}$ to $32.3^{\circ} \mathrm{C}$. The colour changed from ash to faint ash at BOD of $115 \mathrm{mg} / \mathrm{l}$ and COD of $1239 \mathrm{mg} / \mathrm{l}$. The conductivity of the effluent was found to be between the ranges of $1788 \mu \mathrm{S}$ to $1407 \mathrm{mS}$ at $181.9 \mathrm{mg} / \mathrm{l}$ chloride content. 
Table 2. Physicochemical Analysis of the Tannery Effluent at the Beginning and the End of Ten Days Bioremediation Process.

\begin{tabular}{|c|c|c|c|c|c|c|c|c|}
\hline Organisms/Parameters & Temp & Colour & BOD & COD & Conductivity $\left(\mathrm{cm}^{-1}\right)$ & Chloride content & pH & TDS \\
\hline \multicolumn{9}{|l|}{ Before } \\
\hline Pseudomonas aeruginosa & $27.4^{\circ} \mathrm{C}$ & Ash & $942 \mathrm{mg} / \mathrm{L}$ & $1239 \mathrm{mg} / \mathrm{L}$ & $1828 \mu \mathrm{S}$ & $579.8 \mathrm{mg} / \mathrm{L}$ & 6.3 & 1276 ppm \\
\hline Staphylococcus aureus & $27.6^{\circ} \mathrm{C}$ & Ash & $942 \mathrm{mg} / \mathrm{L}$ & $1239 \mathrm{mg} / \mathrm{L}$ & $1903 \mu \mathrm{S}$ & $579.8 \mathrm{mg} / \mathrm{L}$ & 6.3 & 13223 ppm \\
\hline Bacillus sp & $27.4^{\circ} \mathrm{C}$ & Ash & $942 \mathrm{mg} / \mathrm{L}$ & $1239 \mathrm{mg} / \mathrm{L}$ & $1845 \mu \mathrm{S}$ & $579.8 \mathrm{mg} / \mathrm{L}$ & 6.3 & 1292 ppm \\
\hline Saccharomyces cerevisiae & $27.6^{\circ} \mathrm{C}$ & Ash & $942 \mathrm{mg} / \mathrm{L}$ & $1239 \mathrm{mg} / \mathrm{L}$ & $1788 \mu \mathrm{S}$ & $579.8 \mathrm{mg} / \mathrm{L}$ & 6.3 & 1253 ppm \\
\hline \multicolumn{9}{|l|}{ After } \\
\hline Pseudomonas aeruginosa & $32.3^{\circ} \mathrm{C}$ & Faint ash & $1156 \mathrm{mg} / \mathrm{L}$ & $1508 \mathrm{mg} / \mathrm{L}$ & $11.95 \mathrm{mS}$ & $181.9 \mathrm{mg} / \mathrm{L}$ & 8.8 & $8.66 \mathrm{ppt}$ \\
\hline Staphylococcus aureus & $29.1^{\circ} \mathrm{C}$ & Faint ash & $1126 \mathrm{mg} / \mathrm{L}$ & $1480 \mathrm{mg} / \mathrm{L}$ & $12.32 \mathrm{mS}$ & $183.7 \mathrm{mg} / \mathrm{L}$ & 8.8 & $8.66 \mathrm{ppt}$ \\
\hline Bacillus sp & $29.8^{\circ} \mathrm{C}$ & Faint ash & $1028 \mathrm{mg} / \mathrm{L}$ & $1266 \mathrm{mg} / \mathrm{L}$ & $14.07 \mathrm{mS}$ & $190.4 \mathrm{mg} / \mathrm{L}$ & 9.1 & $9.76 \mathrm{ppt}$ \\
\hline Saccharomyces cerevisiae & $28.4^{\circ} \mathrm{C}$ & Faint ash & $1107 \mathrm{mg} / \mathrm{L}$ & $1506 \mathrm{mg} / \mathrm{L}$ & $11.90 \mathrm{mS}$ & $178.5 \mathrm{mg} / \mathrm{L}$ & 8.1 & $8.20 \mathrm{ppt}$ \\
\hline
\end{tabular}

Key: Temp $=$ Temperature, $\mathrm{BOD}=$ Biochemical oxygen demand, $\mathrm{COD}=$ Chemical oxygen demand, TDS $=$ Total dissolved solid, $\mathrm{ppm}=$ part per million

Table 3 shows the final result for physicochemical analysis with their acceptable standard for FEPA and EEPA, in which most of them were found to be beyond the safe limit viz; $\mathrm{pH} 8.2-9.1$ (acceptable $\mathrm{pH}=6.9$ ). In this study, the value of Electric Conductivity along the wastewater channel ranged from $11.90 \mathrm{mS}-14.07 \mathrm{mS}$. The values obtained from all sampling sites were higher than the FEPA standard $(2.500 \mathrm{mS})$ of tannery effluent to be discharged into water body. $\mathrm{BOD}_{5}$ recorded $1028 \mathrm{mg} / \mathrm{l}-1156 \mathrm{mg} / \mathrm{l}$ (against FEPA and EEPA standards of $50 \mathrm{mg} / \mathrm{l}$ and $200 \mathrm{mg} / \mathrm{l}$ respectively); COD recorded $1266 \mathrm{mg} / \mathrm{l}-1508 \mathrm{mg} / \mathrm{l}$ (against FEPA and EEPA standards of $500 \mathrm{mg} / \mathrm{l}$ ); while temperature range of $28.4^{\circ} \mathrm{C}-32.3^{\circ} \mathrm{C}$ is within the acceptable range $\left(<40^{\circ} \mathrm{C}\right.$ and $\left.40^{\circ} \mathrm{C}\right)$; TDS $8.20 \mathrm{ppt}-9.76 \mathrm{ppt}$ (compared to FEPA and EEPA standards of $2000 \mathrm{mg} / \mathrm{l}$ ) and chloride content recorded very low concentration of 181.9 $\mathrm{mg} / \mathrm{l}-190.4 \mathrm{mg} / \mathrm{l}$ after the bioremediation (compared to FEPA and EEPA standards of $1000 \mathrm{mg} / \mathrm{l}$ and $600 \mathrm{mg} / \mathrm{l}$ respectively), hence the chloride content is within the safe acceptable range.
Table 3. Physicochemical Values in Relation to Environmental Protection Agencies Standards.

\begin{tabular}{llll}
\hline Parameters & Sample values & FEPA & EEPA \\
\hline $\mathrm{pH}$ & $8.2-9.1$ & 6.9 & 6.9 \\
Conductivity & $11.90 \mathrm{mS}-14.07 \mathrm{mS}$ & $2500 \mu \mathrm{Scm}^{-1}$ & - \\
$\mathrm{BOD}_{5}$ & $1028 \mathrm{mg} / \mathrm{l}-1156 \mathrm{mg} / 1$ & $50 \mathrm{mg} / 1$ & $200 \mathrm{mg} / 1$ \\
$\mathrm{COD}$ & $1266 \mathrm{mg} / 1-1508 \mathrm{mg} / 1$ & $500 \mathrm{mg} / 1$ & $500 \mathrm{mg} / 1$ \\
Temperature & $28.4^{\circ} \mathrm{C}-32.3^{\circ} \mathrm{C}$ & $\leq 40^{\circ} \mathrm{C}$ & $40^{\circ} \mathrm{C}$ \\
TDS & $8.20 \mathrm{ppt}-9.76 \mathrm{ppt}$ & $2000 \mathrm{mg} / 1$ & - \\
Chloride content & $181.9 \mathrm{mg} / 1-190.4 \mathrm{mg} / 1$ & $1000 \mathrm{mg} / 1$ & $600 \mathrm{mg} / 1$ \\
\hline
\end{tabular}

Key: TDS (Total dissolved solid), mg/l (milligram per litre), BOD (Biochemical Oxygen Demand), COD (Chemical Oxygen Demand), FEPA (Federal Environmental Protection Authority), EEPA (Ethiopian Environmental Protection Authority)

Table 4 shows the efficiency of microbes used in the remediation of the effluent salinity in relation to the initial and final salinity content. All the three organisms recorded a high efficiency of $99.2 \%, 99.2 \%, 99.1 \%$ and $99.2 \%$ for the individual organisms such as Bacillus sp, Saccharomyces cerevisiae respectively while the highest efficiency of $99.9 \%$ was achieved when the microbial consortium was used for the remediation.

Table 4. Efficiency of the Microbes in Bioremediation and Net Abundance of Salinity Before and after the Remediation.

\begin{tabular}{|c|c|c|c|c|c|}
\hline Group & Test organisms & $\begin{array}{l}\text { Initial salinity before } \\
\text { remediation }\left(1^{\text {st }} \text { day }\right)\end{array}$ & Final salinity after remediation $\left(10^{\text {th }}\right.$ day $)$ & Efficiency & Rank \\
\hline \multirow[t]{4}{*}{ Individual microbes } & Pseudomonas aeruginosa & $926 \mathrm{ppt}$ & $7.10 \mathrm{ppt}$ & $99.2 \%$ & II \\
\hline & Staphylococcus aureus & $967 \mathrm{ppt}$ & $7.12 \mathrm{ppt}$ & $99.2 \%$ & II \\
\hline & Bacillus sp & $935 \mathrm{ppt}$ & $8.18 \mathrm{ppt}$ & $99.1 \%$ & III \\
\hline & Saccharomyces cerevisiae & $903 \mathrm{ppt}$ & $7.25 \mathrm{ppt}$ & $99.2 \%$ & II \\
\hline Combinations & Microbial consortium & $905 \mathrm{ppt}$ & $1011 \mathrm{ppm}$ & $99.9 \%$ & I \\
\hline
\end{tabular}

Key: ppt= part per thousand; $p$ pm $=$ part per million

\section{Discussions}

Based on the findings of this research, the predominant isolates obtained from the soil sample analyzed are Gram positive endosporing bacilli, Gram negative bacilli in clusters, Gram positive cocci in clusters and budding cells. The organisms were biochemically characterized as Bacillus sp, Pseudomonas aeruginosa, Staphylococcus aureus and Saccharomyces cerevisiae respectively (Table 1). The identification was carried out as described by Holt [36]. This agrees with the findings of Rahab and Ibrahim [23], who reported that organisms such as Bacillus cereus, Bacillus subtilis, Pseudomonas aeruginosa, Proteus mirabilis, Serretia marcensces, Escherichia coli, Streptococcus pyogenes and Klebsiella pneumoniae can be isolated from soils laden with tannery effluents. Different researchers have reported isolation of various bacterial strains acclimatized on higher concentrations of soil laden effluents. These are Bacillus sp. [37], Pseudomonas putida [38], Bacillus 
thuringiensis [39] and Pseudomonas aeruginosa [40].

Based on the physicochemical analysis, it was found that the temperature of the treated effluent ranged from 27.4 to $32.3^{\circ} \mathrm{C}$; with ash to faint ash colour change; BOD of 942 $\mathrm{mg} / \mathrm{l}, \mathrm{COD}$ of $1239 \mathrm{mg} / \mathrm{l}$, and conductivity ranged from 1788 $\mu \mathrm{S}$ to $14.07 \mathrm{mS}$ respectively (Table 2). The levels of $\mathrm{BOD}_{5}$ and COD are beyond the statutory acceptable limit even after the bioremediation. This may be due to the accumulation of microbial biomass following decrease in the salinity and total dissolved solids. This agrees with the studies of Joshi and Santani [41], who recorded high COD and BOD values which are not in compliance with standards. Halophilic microorganisms are of increasing interest in industrial waste treatment, due to their ability to degrade hazardous substances efficiently under high salt conditions. However, their full potential remains unexplored [7]. Based on the physicochemical analysis in comparison with FEPA [42] and EEPA [43] standards (Table 3), it was found that $\mathrm{pH}$, conductivity, $\mathrm{BOD}_{5}$ and $\mathrm{COD}$ are above the standard limits, which could be as a result of decrease or reduction of salt content in the effluent, which gives way for other organisms to invade and multiply thereby increasing microbial activities in the effluent, while the chloride contents are within the acceptable range. This disagrees with the findings of Reda [24] who recorded chloride contents of 5555 to $6111 \mathrm{mg} / \mathrm{l}$ from the tannery effluents. Hence, paired sample t-test (SPSS version 16.0) showed that there is significant difference $(P=$ 0.000 at 0.005 level of significance) between the chloride content of the tannery effluent before bioremediation and the chloride content after ten days of bioremediation. Based on the efficiency of the microbes used in the remediation of salinity in the tannery effluent, it was found that the combination of the test organisms (i.e. the microbial consortium) recorded high efficiency of $99.9 \%$ salinity remediation. The individual organisms recorded a prominent efficiency in the remediation of tannery effluent salinity with Saccharomyces cerevisiae (99.2\%), Staphylococcus aureus (99.2\%) and Pseudomonas aeruginosa (99.2\%) ranking as second to the microbial consortium in terms of remediation efficiency. Bacillus sp (99.1\%) was ranked third in terms of bioremediation efficiency (Table 4). The ranking agrees with but the efficiency is relatively higher than the findings of Benazir et al. [26] who reported that Saccharomyces cerevisiae was ranked second (95.6\%) in terms of efficiency in the tannery effluent bioremediation. But, it contradicts the findings of Benazir et al. [26] who reported first and third efficiency rankings for Bacillus subtilis (99.6\%) and Pseudomonas aeruginosa (99.6\%) respectively.

\section{Conclusion and Recommendation}

\subsection{Conclusion}

This research revealed the ability of halophilic microbial consortium in the aerobic bioremediation or degradation of salinity in tannery effluent. The isolation, characterization and identification of halophilic microbes such as
Pseudomonas aeruginosa, Bacillus sp, Staphylococcus aureus and Saccharomyces cerevisiae from hypersaline environment supported their application in bioremediation process. The tannery effluent was characterized by physicochemical analysis of parameters such as; $\mathrm{pH}$, colour, TDS, temperature, conductivity, salinity, $\mathrm{COD}$ and $\mathrm{BOD}_{5}$, which were analyzed and compared with FEPA and EEPA standards. The salinity, chloride content and temperature of the treated effluent were found to fall within the acceptable range. The application of halophilic microbial consortium remedied salinity with highest efficiency compared to the individual isolates used in the remediation. The salinity reduced from $905 \mathrm{ppt}$ to $1101 \mathrm{ppm}$ during the ten days bioremediation, which accounted for $99.9 \%$ reduction in the salt content from the effluent.

\subsection{Recommendations}

a) Tannery effluents should be treated with biological methods before discharging to the environment or water bodies because, high salinity can primarily decrease the rate of enzymatic activity of non-halophilic and non-halotolerant organisms, thereby affecting the ecosystem, since salinity can cause dehydration to potential microbes that are not halophilic and halotolerant, wither crops leaves and also affect human health.

b) The industries should employ the use of halophilic microbes in the biological remediation of salinity rather than the use of chemicals which are carcinogenic in nature and can cause other health effects on humans.

\section{References}

[1] USEPA (2001). Washington, DC. Secondary Treatment Regulation. U. S. Environmental Protection Agency. Code of Federal Regulations, 40; 76: 1147-1153. doi: 10.1002/ jctb.497.

[2] Uberoi, N. K. (2003). Environmental Management. Excel Books Publisher, New Delhi, pp: 269.

[3] Kongjao, S., Damronglerd, S. and Hunsom, M. (2008). Simultaneous removal of organic and inorganic pollutants in tannery wastewater using electrocoagulation technique. Korean J. Chem. Eng., 25: 703-709.

[4] Mann, D. K., Hurt, T. M., Malkos, E., Sims, J., Twait, S. and Wachter, G. (1996). Onsite treatment of petroleum, oil, and lubricant (POL)-contaminated soils at Illinois Corps of Engineers lake sites. US Army Corps of Engineers Technical Report No. A862603: 1-71.

[5] Sims, G. K. (2006). Nitrogen Starvation Promotes Biodegradation of N-Heterocyclic Compounds in Soil. Soil Biology \& Biochemistry 38: 2478-2480. doi: 10.1016/j.soilbio.2006.01.006.

[6] O'Loughlin, E. J., Traina, S. J. and Sims, G. K. (2000). Effects of sorption on the biodegradation of 2methylpyridine in aqueous suspensions of reference clay minerals. Environ. Toxicol. Chem., 19: 2168-2174. doi: 10.1002/etc.5620190904. 
[7] Castillo-Carvajal, L. C., Sanz-Martin, J. L. and BarragànHuerta, B. E. (2014). Biodegradation of organic pollutants in saline wastewater by halophilic microorganisms: A review. Environ. Sci. Pollut. Res. Int., 21 (16):9578-9588. Doi: 10.1007/s11356-3036-Z.

[8] Mena, E., Villasenor, J., Canizares, P., Rodrigo, M. A. (2016). Performance of soil electron bioremediation. Journal Chemosphere Metabol., 20: 1-4.

[9] Tariq, S. R., Shaheen, N.A., Khalique, S. (2005). Multivariate analysis of selected metals in tannery effluents and related soil. J. Hazard. Mater., 122: 17-22.

[10] Apte, A. D. Verma, S., Tare, V. and Bose, P. (2005). Oxidation of $\mathrm{Cr}$ (iii) in tannery sludge to $\mathrm{Cr}$ (vi): Field observations and theoretical assessment. J. Hazard. Mater., 121 (1-3): 215-222.

[11] Leghouchi, E. Laib, E. Guerbet, M. (2009). Evaluation of chromium contamination in water, Sediment and vegetation caused by the tannery of Jijel (Algeria): a case study. Environ. Monit. Assess., 153: 111-117. doi: 10.1007/s10661-008-03413.

[12] Owlad, M., Aroua, M. K., Daud, W. A. A. and Baroutian, S. (2008). Removal of hexavalent chromium-contaminated water and waste water. Water, Air, and Soil Pollution, 200: 59-77.

[13] Ram, C., Narsh, R., Gava, B., Kapley, A., Purohit, H. (2011). Bacterial diversity, organic pollutant and metabolites in two aeration lagoons of common on effluent by treatment plant (CETP) during the degradation and toxification of tannery wastewater. Biores. Technol., 102: 2333-1.

[14] Hinteregger, C. and Streichsbier, F. (1997). Halomonas sp., a moderately halophilic strain, for biotreatment of saline phenolic waste-water. Biotechnol. Lett. 19 (11):1099-1102.

[15] Santos, C. A., Vieira, A. M., Fernandes, H. L., Empis, J. A. and Novais, J. M. (2001). Optimisation of the biological treatment of hypersaline wastewater from Dunaliella salina carotenogenesis. Journal of Chemical Technology and Biotechnology.

[16] Kubo, M., Hiroe, J., Murakami, M., Fukami, H. and Tachiki, T. (2001). Treatment of hypersaline-containing wastewater with salt-tolerant microorganisms. J Biosci. Bioeng., 91: 222224. doi: $10.1263 / \mathrm{jbb} .91 .222$.

[17] Woolard, C. R. and Irvine, R. L. (1995). Treatment of hypersaline wastewater in the sequencing batch reactor. Water Res., 29: 1159-1168.

[18] Bray, E. A., Bailey-Serres, J. and Weretilnyk, E. (2000). Responses to abiotic stresses. In: Gruissem W, Buchannan B, Jones R, editors. Biochemistry y Molecular Biology of Plants. Rockville, MD, USA: Ameri. Soc. of Plant Physiologists, $1158-1249$

[19] Kargi, F. (2002). Enhanced biological treatment of saline wastewater by using halophilic bacteria. Biotechnol. Lett., 24: $1569-1572$.

[20] Carlos, K., Katarzyna, W., Kazimierg, W., Juan, M. M., Laura, E., Nara, L. and Gomez, R. G. (2002). Possible adverse effects of chromium in occupational exposure of tannery workers. Industrial Health, 40: 207-213.

[21] Umar, M., Ibrahim, M. A., Mustapha, M. B., Mohammed, I. B., Tashi, U. T., Obafemi, A. and Ahmad, G. I. (2017). Physicochemical Analysis and Microbiological Assessment of
Tannery Effluent Discharged from Tanneries around Nigeria's Kano Industrial Estates. Journal of Advances in Microbiology, 2 (1): 1-12. doi: 10.9734/JAMB/2017/31437.

[22] Orji, M. U., Nwokolo, S. O. and Okolo, I. (2006). Effect of palm oil mill effluent on soil microflora. Nig. J. Microbio., 20 (2): 1026-1031.

[23] Rabah, A. B. and Ibrahim, M. L. (2010). Physicochemical and Microbiological characterization of soils laden with tannery effluent in Sokoto Nigeria. Nigerian Journal of Basic and Applied Science, 18 (1): 65-71.

[24] Reda, A. H. (2016). Physico-chemical characterization of tannery effluent and its impact on the nearby river. Journal of Environmental Chemistry and Ecotoxicology, 8 (6): 44-50.

[25] Clesceri, L. S., Greenberg, A. E. and Trussel, R. R. Eds. (1989). In Standard Methods for the Examination of Water and Wastewater, $17^{\text {th }}$ ed, American public health association AWWA, WPCF. Washington DC.

[26] Benazir, J. F., Suganthi, R., Rajvel, M., Padmini, P. and Mathumilia, B. (2010). Bioremediation of chromium in tannery effluent by microbial consortia. African Journal of Biotechnology, 9 (21): 3140-3143.

[27] Cheesbrough, M. (2006). District Laboratory Practice in Tropical Countries. Part 2. Low Price Edition. Cambridge University Press, London, pp 28-90.

[28] Umar, M., Akafyi, D. E., Abdulkarim, I. M., Yaya, A. A. and Danasabe, Y. J. (2015). Biochemical Characterization and Antibiogram Pattern of Streptococcus mutans Isolated from Dental Unit, Sick-bay, Ahmadu Bello University, Zaria, Nigeria. International Journal of Biological and Biomedical Sciences, 4 (10): 063-066.

[29] Ono, B. I., Ishi, N., Fujino, S. and Aoyama, I. (1991). Physiological Characterization of Yeasts Isolated from Artisanal Fermentation in Aguardente Distillery. Rev. Microbiol., 29: 104-108.

[30] Guimarães, T. M., Moriel, D. G., Machado, I. P., Fadel Picheth, C. M. T. (2006). Isolation and Characterization of Saccharomyces cerevisiae Strains of Winery Interest. Brazilian Journal of Pharmaceutical Sciences, 42 (1): 119126.

[31] APHA (1998). Standard Methods for the Examination of Water and Wastewater. 20th ed, American Public Health Assocation. Washington, D. C.

[32] Ademoranti, C. M. A. (1996). Standard methods for water effluent analysis. 1st edition, Fokudex Press Ltd, Ibadan, Nigeria: 111-117.

[33] Sadiq, S. I. and Malami, S. (2009). Comparative study of the effect of tanner effluents on two major streams in Sokoto State, Nigeria. Nig. J. Basic Appl. Sci., 17 (1): 48-52. doi:10.5897/JECE2015.0365.

[34] Douglas L. K. (2009). Soil/water product: The use of Spectrum Waterproof EC meter. Retrieved on $11^{\text {th }}$ December, 2016. Available on www.agrometria.it/sites/default/files/prodotti documentazione /EC\%25202246_Waterproof.pdf\&sa=U\&ved=oahUKEwiV5N bEn-

_TAhVGI8AKHaL7BLUQFggXMAY\&sig2=cjGY8iDO3iW2

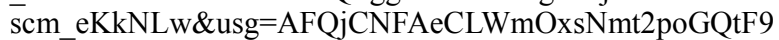
OOoqGQ. 
[35] Jones, H. (1952). The Science of colour. Thomas Y. Cowell Co., New York, N. Y, USA. In: Standard Methods for Examination of Water and Wastewater. APHA Water Works Association of 1999. Water Environment Federation: 1-7.

[36] Holt, J. G, Kreig. N. R, Senalth, P., Stanley, J. and William, S. (2004). Bergey's Manual for the Determinative Bacteriology. Pp.122.

[37] Kaushik, G. and Thakur, S. (2009). Isolation and Characterization of Distillery spent wash Color Reducing Bacteeria and Process Optimization by Taguchi Approach. Int. Biodeterior. Biodegradation, 63: 420-426.

[38] Ghosh, M., Ganguli, A. and Tripathy, A. K. (2002). Treatment of anaerobically digested distillery spentwash in a two-stage bioreactor using Pseudomonas putida and Aeromonas sp. Process Biochem., 37: 857-862.

[39] Kumar, P. and Chandra, R. (2006). Decolorisation and Detoxification of Synthetic Molasses Melanoidins by individual and mixed cultures of Bacillus spp. Bioresour. Technol., 97 (16): 2096-2102.
[40] Mohana, S., Desai, C. and Madamwar, D. (2007). Biodegradation and decolourization of anaerobically treated distillery spent wash by a novel bacterial consortium. Bioresour. Technol., 98: 333-339.

[41] Joshi V. J. and Santani D. D. (2012). Physicochemical Characterization and Heavy Metal Concentration in Effluent of Textile Industry. Universal Journal of Environmental Research and Technology, 2 (2): 93-96.

[42] FEPA (1991). Federal Environmental Protection Agency: Guidelines to Standards for Environmental Pollution Control in Nigeria, FG Press Lagos, Nigeria, 238.

[43] EEPA (2001). Situation analysis; the industrial sector. ESID project US/ETH/99/068/ETHIOPIA, EPA/UNIDO. Ethiopian Environmental Protection Authority. Addis Ababa, Ethiopia. 